\title{
STRATEGI MANAJEMEN KOMUNIKASI PADA BOGOR NGARIUNG
}

\section{COMMUNICATION MANAGEMENT STRATEGY ON BOGOR NGARIUNG}

\author{
Robby Firliandoko1a, Muhammad Luthfie², AA Kusumadinata ${ }^{3 a}$ \\ ${ }^{123}$ Program studi Ilmu Komunikasi, Fakultas Ilmu Sosial Dan Ilmu Politik, \\ Universitas Djuanda Bogor Jl. Tol Ciawi No 1 Kotak Pos 35 Bogor 16740 \\ 13a"Korespondensi: 1aRobby Firliandoko , Email: robby.firliandoko@gmail.com \\ 3aAA Kusumadinata, Email: alialamsyahkusumadinata@gmail.com
}

(Diterima: 10-02-2018; Ditelaah: 12-02-2018 ; Disetujui: 14-02-2018 )

\begin{abstract}
Since was born and do their life human being always need help other people in order almost all of the human being join or make a group, community and also organization for easyly their work and take what their want. In Bogot City, presence of community have been a phenomenon, community not only fo what their hobbie but also be changemakers and contribute to environment with their ways and their called community of change. And the interest thing is Bogor City have the only one organization is accommodate community and organization changemakers are not owned by another city called Bogor Ngariung. Goals of the research was wanted to analize audit organization communication on Bogor Ngariung with the focus of study (1) to analize organization communication Bogor Ngariung, (2) to satisfaction analize of members on Bogor Ngariung, and what be drivess factor of members to get satisfaction, (3) to formulate management strategy of Bogor Ngariung to give satisfaction to members. This research done by qualitative method. The result showed (1) networking was a good thing for the organization, so the relationship between members was also good was a good organizational communication activities and needs to be strengthened by the activities of direct meetings or Ngariung Communities and the selection of appropriate communication media, (2) the satisfaction of members of Bogor Ngariung towards the communication organization in Bogor Ngariung environment was encouraged by the easy networking with other members by using communication media and integration of activities, (3) management strategy Bogor Ngariung to provide satisfaction to members was realized through networking and integration of members by optimizing the use of communication media.
\end{abstract}

Keywords: Audit Organization Communication, Bogor Ngariung, Communication Satisfaction

\section{ABSTRAK}

Sejak lahir dan dalam menjalankan kehidupan manusia selalu membutuhkan bantuan orang lain sehingga hampir semua bergabung atau membentuk kelompok, komunitas, atau juga organisasi demi memudahkan pekerjaan dan juga menggapai apa yang ingin digapai. Di Kota Bogor sendiri, geliat hadir dan menjamurnya komunitas sudah menjadi fenomena, komunitas tidak hanya melakukan kegiatan dari mulai yang mereka senangi namun juga melakukan perubahan dan kontribusi kepada lingkungan melalui jalurnya masing-masing yang bisa juga disebut komunitas dan organisasi pegiat perubahan. Dan menariknya, Kota Bogor memiliki satu-satunya organsiasi yang mewadahi komunitas dan organisasi pegiat perubahan yang tidak banyak dimiliki oleh kota lain dengan nama Bogor Ngariung. Tujuan penelitian ini menganalisis audit komunikasi organisasi yang ada di lingkungan organisasi Bogor Ngariung dengan fokus studi pada (1) analisis komunikasi organisasi di Bogor Ngariung, (2) menganalisis kepuasan anggota terhadap Bogor Ngariung, serta faktor yang menjadi pendorong anggota untuk mendapatkan rasa puas, (3) merumuskan strategi manajemen Bogor Ngariung untuk memberikan kepuasan kepada anggota. Penelitian ini menggunakan metode kualitatif. Adapun hasil penelitian yang dihasilkan adalah (1) Jejaring merupakan hal yang berdampak baik bagi organisasi, 
sehingga hubungan antar anggota juga baik merupakan kegiatan komunikasi organisasi yang baik dan perlu diperkuat dengan kegiatan pertemuan langsung atau Ngariung Komunitas dan pemilihan media komunikasi yang sesuai, (2) Rasa puas anggota Bogor Ngariung terhadap komunikasi organsisasi di lingkungan Bogor Ngariung didorong oleh mudahnya berjejaring dengan anggota lain dengan menggunakan media komunikasi dan integrasi kegiatan. (3) Strategi manajemen Bogor Ngariung untuk memberikan kepuasan kepada anggota diwujudkan melalui .jejaring dan integrasi sesama anggota dengan mengoptimalkan penggunaan media komunikasi.

Kata Kunci : Audit Komunikasi Organisasi, Bogor Ngariung, Kepuasan Komunikasi

R Firliandoko, M Luthfie, AA Kusumadinata. 2018. Strategi Manajemen Komunikasi pada Bogor Ngariung. Jurnal Komunikatio 4(1): 13-26. 


\section{PENDAHULUAN}

Manusia selalu melakukan aktivitas sosial melalui interaksi sosial. Soekanto (2015) menjelaskan bahwa bentuk umum proses sosial adalah interaksi sosial (yang juga dapat dinamakan proses sosial) karena interaksi sosial merupakan syarat terjadinya aktivitas-aktivitas sosial. Interaksi sosial merupakan hubunganhubungan sosial yang dinamis yang menyangkut hubungan antar orang-orang perorangan, antar kelompok-kelompk manusia, maupun antara orang perorangan dengan kelompok manusia.

Sebagai makhluk sosial, interaksi sesama manusia dan sesama kelompok menjadi hal yang utama. Bagaikan kebutuhan batin, interaksi menjadi sebuah hal yang pasti dilakukan oleh setiap individu. Interaksi dilakukan dengan berbagai macam cara dan tidak hanya melalui tutur bicara. Bahkan, individu yang memiliki kekurangan dalam berbicara atau tuna wicara juga menggunakan bahasa isyarat untuk mengirim dan menerima pesan dalam melakukan interaksi sosial. Interaksi sosial digunakan tidak hanya untuk mengirim dan menerima pesan, melainkan juga untuk memahami, menelaah dan mempelajari masalahmasalah yang terjadi di masyarakat. Soekanto (2015) menjelaskan mengenai syarat-syarat terjadinya interaksi sosial, suatu interaksi sosial tidak akan mungkin terjadi apabila tidak memenuhi dua syarat, yaitu adanya kontak sosial dan adanya komunikasi.

Komunikasi menjadi hal utama dalam melaksanakan interaksi sosial. Seperti hal yang sudah dijelaskan oleh Soekanto (2015) interaksi sosial yang berada di tengah masyarakat tidak akan menjadi sebuah interaksi sosial bila tidak adanya komunikasi antara individu maupun antara individu dengan kelompok maupun kelompok dengan kelompok. Komunikasi memiliki peranan penting dalam setiap individu dan juga di dalam masyarakat. Komunikasi digunakan oleh individu untuk mengirim dan menerima pesan melalui mediumnya masing-masing.

Seiring berkembangnya kebutuhan dan keinginan individu pula, perkembangan teknologi komunikasi selalu diupakan memiliki perubahan dan inovasi demi mendukung dan memudahkan individu dalam melakukan komunikasi sehingga interaksi sosial menjadi semakin mudah dilakukan. Perkembangan teknologi komunikasi juga tidak hanya menciptakan komunikasi yang hanya dalam lingkungan kecil, di era teknologi yang semakin maju ini, individu memungkinkan melakukan komunikasi dengan individu lainnya yang berasal dari negara yang berbeda. Devito (Ruliana 2016) mengemukakan bahwa komunikasi mengacu pada tindakan satu orang atau lebih yang mengirim dan menerima pesan, terjadi dalam suatu konteks tertentu, mempunyai pengaruh tertentu, dan ada kesempatan untuk melakukan umpan balik (feedback) yang dipengaruhi oleh lingkungan (konteks) di mana komunikasi itu terjadi. Komunikasi interaksional mendeskripsikan apa yang dinamakan komunikasi yang bersifat interaksional yang mengandung elemenelemen yang ada dalam setiap tindak komunikasi, terlepas apakah itu bersifat intrapribadi, antarpribadi, pidato terbuka, komunikasi massa atau kelompok.

Barnard (Kertonegoro 1994) mencoba mempertegas hubungan individu dengan kelompok, menurutnya, manusia berkelompok dalam organisasi untuk mencapai sesuatu yang tidak bisa mereka capai secara individual. Namun, sambil mengejar tujuan organisasi, mereka juga harus memenuhi kebutuhan individualnya. Barnard sampai pada pokok thesisnya bahwa perusahaan akan tetap hidup dan berjalan efisien jika tujuan organisasi 
maupun kebutuhan anggotanya dijaga keseimbangannya.

kini individu juga memiliki kebebasan untuk bergabung dengan berbagai jenis organisasi. Selain organisasi, komunitas juga menjadi sekumpulan individu yang dipilih oleh individu untuk memenuhi keinginannya dan juga menggapai tujuan yang diharapkan. Crow dan Alan (Dudung 2015) menjelaskan bahwa komunitas dapat terbagi menjadi tiga, yaitu: .Berdasarkan Lokasi atau Tempat, Berdasarkan Minat atau Hobi, dan Berdasarkan Komunitas.

Dari ketiga penjelasan mengenai pembagian komunitas menurut Crow dan Allan (Dudung, 2015), komunitas dan organisasi yang tergabung di Bogor Ngariung termasuk ke dalam jenis komunitas yang terbentuk berdasarkan ide atau komunitas komuni. Komunitas dan organisasi yang tergabung di Bogor Ngariung membangun komunitas atas dasar permasalahan yang ada kemudian menciptakan ide dan aksi untuk memecahkan permasalahan yang ada di sekitarnya dan di Kota Bogor.

Kota Bogor sendiri, geliat organisasi dan komunitas telah menjadi fenomena, hal itu dapat dilihat dari pemberitaan yang diberitakan pada laman resmi Pemerintah Kota Bogor dengan judul Bima Arya Buka Puasa Bersama dengan Puluhan Komunitas (Lani dan Hari, 2017) WALIKOTA Bogor menjelaskan bahwa pada bulan Ramadhan ini di Balaikota hanya empat kali buka bersama yang khusus menjadi ajang pertemuan yaitu dengan Muspida (Musyawarah Pimpinan Daerah), pimpinan Partai, Dewan Perwakilan Rakyat Daerah (DPRD) Kota Bogor, Majelis Ulama Indonesia (MUI) Kota Bogor atau alim Ulama, pelaku UMKM dan terakhir dengan komunitas sebagai mitra Pemkot Bogor.

Selain hadir banyaknya organisasi dan komunitas pegiat perubahan di Bogor, adanya wadah komunitas dan organisasi yang mewadahi organisasi dan komunitas pegiat perubahan di Bogor juga menjadi salah satu sorotan yang menarik bagi peneliti. Sejak 8 Maret 2014 wadah yang bernama Bogor Ngariung hadir sebagai wadah komunitas dan organisasi pegiat perubahan yang ada di Bogor untuk saling berkoordinasi dan menciptakan sinergisitas agar dampak perubahan yang dilakukan semakin besar. Bergerak, bersama dan saling menginspirasi adalah ruh yang coba diciptakan bersama oleh Bogor Ngariung. Komunitas dan organisasi pegiat perubahan di Bogor percaya bahwa dengan bergerak bersama perubahan akan semakin besar dan berdampak untuk masyarakat, dengan begitu akan semakin mudah menggapai mimpi bersama yaitu menciptakan Bogor yang lebih baik melalui aksi komunitas dan organisasi pegiat perubahan. Hal ini merupakan bentuk koalisi dari kerja sama yang dihasilkan dari proses asosiatif. Dimana dua organisasi atau lebih yang mempunyai tujuan-tujuan yang sama kemudian melakukan kerja sama satu dengan lainnya untuk mecapai tujuan tersebut (Bungin 2013).

Penelitian terhadap komunikasi organisasi di lingkungan Bogor Ngariung perlu dilakukan mengingat tidak banyak kota yang memiliki wadah untuk komunitas lokalnya. Peneliti sudah mencoba mengadakan pengamatan dan berdiskusi dengan pegiat komunitas nasional dan hasilnya hanya ada beberapa kota yang memiliki wadah untuk komunitas pegiat perubahan di kota masing-masing, diantaranya: Yogyakarta dengan Forum Jogja Peduli, Malang dengan Ngalam Community, Bandung dengan Bandung Creative City Forum dan Bogor dengan Bogor Ngariung. Selain itu, Bogor Ngariung kini juga sudah mewadahi 99 anggota. Banyaknya komunitas dan organisasi yang tergabung, akan berusia empat tahun, menjadi salah satu wadah komunitas lokal di Indonesia menjadi beberapa pertimbangan penelitian ini dilakukan untuk mengaudit komunikasi organisasi di lingkungan Bogor Ngariung agar Bogor Ngariung bisa terus 
berkembang sesuai tujuan audit komunikasi.

Audit komunikasi organisasi sendiri menurut Andre Hardjana (Kriyantono 2012) adalah sebuah analisis yang komplet terhadap komunikasi dari sebuah organisasi internal dan/atau eksternal dirancang untuk take a picture (memotret) kebutuhan komunikasi, kebijakan, maupun praktik-praktiknya untuk mengcover data yang memungkinkan top manajemen mendapat informasi, membuat keputusan ekonomi tentang tujuan-tujuan komunikasi organisasi di masa depan. Audit komunikasi merupakan kajian mendalam dan menyeluruh tentang pelaksanaan sistem komunikasi keorganisasian yang mempunyai tujuan untuk meningkatkan efektivitas organisasi. Secara umum, audit komunikasi organisasi digunakan untuk memonitor dan mengevaluasi media, pesan-pesan, dan iklim komunikasi dalam organisasi.

Penelitian ini menjadi semakin penting dimana peran komunitas dan organisasi pegiat perubahan beserta Bogor Ngariung sebagai organisasi yang mewadahi diapresiasi langsung oleh Sekertaris Daerah Kota Bogor, Ade Syarif Hidayat yang terdapat pada pemberitaan media massa (Desya dan Wira 2017) dengan judul Saatnya Komunitas Bogor Menjadi Pegiat Perubahan.

Beberapa penelitian serupa Ramadani (2015) menemukan bahwa sistem komunikasi organisasi WALHI Yogyakarta setelah di audit mampu berjalan dengan baik, dengan pendekatan komunikasi vertikal dan horizontal. Temuan lain adalah penggunaan media tertulis dan media elektronik merupakan penunjang kelancaran komunikasi dan audit komunikasi. Beberapa penelitian lain Sari (2009) melihat komunikasi yang efektif sangat menentukan kelangsungan hidup dan kesehatan suatu organisasi. Untuk dapat mengetahui apakah kegiatan komunikasi yang sudah dijalankan efektif atau berhasil mencapai tujuan dan sasaran organisasi adalah dengan melakukan audit komunikasi.

Oleh karena itu, pentingnya sebuah audit komunikasi dalam sebuah organisasi. Adapun tujuan penelitian ini adalah : (1) Menganalisis komunikasi organisasi di Bogor Ngariung. (2) Menganalisis kepuasan anggota terhadap Bogor Ngariung, serta faktor yang menjadi pendorong anggota untuk mendapatkan rasa puas. Merumuskan strategi manajemen Bogor Ngariung untuk memberikan kepuasan kepada anggota di dalam organisasi Bogor Ngariung.

\section{Kerangka Teori}

Komunikasi dan organisasi merupakan sesuatu yang erat. Goldhaber (Ruliana 2016) menjelaskan bahwa komunikasi organisasi adalah proses menciptakan dan saling bertukar pesan dalam satu jaringan hubungan yang saling tergantung satu sama lain untuk mengatasi lingkungan yang tidak pasti atau berubah-ubah.

Liliweri (Ruliana 2016) mengemukakan bahwa ada empat tujuan komunikasi organisasi, yakni (1) menyatakan pikiran, pandangan dan pendapat, (2) membagi informasi, (3) menyatakan perasaan dan emosi, (4) melakukan koordinasi.

Organisasi yang baik adalah organisasi yang baik dalam aktivitas komunikasinya, dan untuk mengetahui bagaimana komunikasi sudah terjadi, sebuah organisasi memerlukan audit komunikasi. Mohammed dan Bungin (2015) menjelaskan mengapa audit komunikasi sangat penting dilakukan. Komunikasi adalah unsur utama yang menjadi penggerak proses pengelolaan sebuah organisasi. Beberapa penelitian menunjukan bahwa dalam manajemen di sebuah organsiasi kebanyakan waktu yang digunakan adalah untuk berkomunikasi. Ulasan beberapa sarjana menunjukan $80 \%$ waktu yang digunakan oleh para manajer adalah untuk berkomunikasi dengan orang 
lain, termasuk komunikasi dengan bawahan, rekan kerja, atasan, pelanggan, dan pemasok. Aktivitas berkomunikasi ini dilakukan untuk tujuan menggerakkan ke arah pencapaian tujuan organisasi atau tujuan pribadi.

Pace dan Faules (Kriyantono 2012) menjelaskan bahwa kepuasan komunikasi berarti anggota organisasi merasa nyaman dengan pesan-pesan, media, dan hubungan-hubungan dalam organisasi. Kepuasan komunikasi mencakup kualitas media, kecukupan informasi, informasi yang berkaitan dengan pekerjaan kemampuan untuk menyarankan perbaikan, efisiensi berbagai saluran komunikasi ke bawah, cara sejawat berkomunikasi, informasi tentang organisasi secara keseluruhan dan integrasi organisasi

\section{METODE PENELITIAN}

Metode pengkajian yang digunakan dalam penelitian ini adalah pendekatan kualitatif. bertujuan untuk menjelaskan fenomena dengan sedalam-dalamnya. Riset ini tidak mengutamakan besarnya populasi atau sampling bahkan populasi atau samplingnya sangat terbatas dengan lebih ditekankan adalah persoalan kedalaman (kualitas) data bukan banyaknya (kuantitas) data. Periset adalah bagian integral dari data, artinya periset ikut aktif dalam menentukan jenis data yang diinginkan. Dengan demikian, periset menjadi instrumen riset yang harus terjun langsung di lapangan (Kriyantono 2012).

Tipe penelitian ini menggunakan tipe deskripsi kualitatif, dimana peneliti mendeskripsikan atau mengkonstruksi wawancara-wawancara mendalam terhadap subjek penelitian. Di sini peneliti bertindak selaku fasilitator dan realitas dikonstruksi oleh subjek penelitian. Selanjutnya peneliti bertindak sebagai aktivis yang ikut memberi makna secara kritis pada realitas yang dikonstruksikan subjek peneliti. Data dikumpulkan melalui wawancara mendalam. Wawancara mendalam adalah suatu cara mengumpulkan data atau informasi dengan cara langsung bertatap muka dengan informan agar mendapatkan data lengkap dan mendalam (Kriyantono 2012). Wawancara penelitian ini dilakukan kepada 7 perwakilan anggota dari 7 bidang yang sesuai dengan kriteria penelitian, adapun informan tersebut adalah: Bogor Clean Action dari bidang lingkungan, Berkawan Indonesia dari bidang literasi, Paguyuban MOKA Kota Bogor bidang sejarah, seni dan budaya, Rumah Merah Putih dari bidang pendidikan, Rainheart dari bidang sosial, Kertas Quilling dari bidang seni, dan PERHUMAS Muda Bogor dari bidang media dan komunikasi.

Analisis data dalam pendekatan kualitatif didahului oleh upaya mengungkapakan trustworthiness dari para subjek penelitian. Yaitu menguji kebenaran dan kejujuran subjek penelitian dalam mengungkap realitas. Trustworthiness ini diuji melalui pengujian: kredibilitas subjek, dengan menguji jawaban-jawaban pertanyaan berkaitan dengan pengalaman dan pengetahuan mereka yang khas. Berikutnya adalah menguji authenticity, yaitu peneliti memberi kesempatan dan memfasilitasi pengungkapan konstruksi personal yang lebih detail (Kriyantono 2012). 


\section{HASIL DAN PEMBAHASAN}

\section{Komunikasi Organisasi di Bogor Ngariung}

\section{Media Komunikasi}

Media komunikasi merupakan alat yang paling utama dalam melalukan aktivitas komunikasi organisasi. Sejak awal dibentuk, Bogor Ngariung memanfaatkan aplikasi bertukar pesan LINE untuk menghubungkan antar anggota dan untuk berkomunikasi dalam bentuk grup atau biasa disebut grup LINE.

Namun, setelah hampir lebih dari tiga tahun, saat ini anggota Bogor Ngariung banyak yang aktif menggunakan Whatsapp dibanding LINE. Perpindahan whatsapp sebagai grup koordinasi dinilai akan melancarkan alur komunikasi di dalam grup Bogor Ngariung, hal itu diperkuat oleh Masitoh (2015) yang menemukan bahwa sebagai media komunikasi whatsapp memiliki empat peran, diantaranya adalah: fungsi informatif, fungsi regulatif, fungsi integratif dan fungsi persuasif.

Mengenai informasi di dalam grup, informan merasa bahwa informasi yang ada di dalam grup hampir semua merasakan sesuai dengan kebutuhan anggota, selain untuk berjejaring, grup juga sering menyampaikan informasi tentang kegiatan. Selain itu, informan juga berharap bahwa grup koordinasi dapat digunakan untuk membahas masalah dan solusi dari anggota. Hal itu dapat dilakukan karena menurut Adhi (2014) grup WA memungkinkan para penggunanya untuk menyampaikan pengumuman tertentu, berbagi ide dan sumber pembelajaran, serta mendukung terjadinya diskusi secara online. Hal ini didukung oleh hasil penelitian Sukrillah et al. (2017) grup WAG mampu meningkatkan efisiensi dalam berkomunikasi dengan melibatkan setiap admin dan anggota senantiasa menyimak informasi yang diberikan serta melakukan diskusi terbuka dalam meningkatkan persepsi yang sama terhadap anggota.

\section{Ngariung Komunitas}

Selain berkoordinasi menggunakan media bertukar pesan LINE, Bogor Ngariung juga memiliki kegiatan kumpul rutin yang bernama Ngariung. Dari hasil penelitian di lapangan bersama informan, peneliti mendapatkan fakta bahwa Ngariung merupakan kegiatan yang ditunggu, karena dalam kegiatan tersebut seluruh anggota dapat bertemu dengan anggota yang lain, sehingga bisa saling mengenal dan bisa menjalin kolaborasi untuk kegiatan bersama. Pertemuan anggota secara rutin perlu dilakukan untuk dapat memupuk rasa persaudaraan dan solidaritas sesama anggota, Setyawan (2016) menemukan bahwa solidaritas internal komunitas Honda Classic Magelang "Cub Series" adalah dengan kegiatan peduli lingkungan, outbond, dan kopi darat di rumah pengurus.

Ngariung atau pertemuan secara langsung diharapkan dapat menjadi ajang belajar untuk upgrade ilmu untuk komunitas dengan menghadirkan pembicara-pembicara yang baik dan tidak hanya kumpul saja, hal ini didukung oleh hasil penelitian Anna (2009) yang menjelaskan pentingnya peranan knowledge bagi keberlangsungan organisasi di era globalisasi ekonomi, tidaklah aneh jika saat ini organisasi lebih memperkuat organizational knowledge mereka dengan mengimplementasikan knowledge management dan membudayakan knowledge sharing dalam organisasi.

\section{Hubungan Anggota}

Hubungan baik ini merupakan hasil yang baik karena selain tanpa konflik, anggota juga ada beberapa yang membangun hubungan yang lebih baik seperti menjadi teman yang baik yang saling mendukung. Hubungan baik sesama anggota merupakan 
salah satu kunci kesuksesan sebuah organisasi, hal ini juga dituturkan oleh penelitian Setyono (2013) yang menemukan bahwa kualitas komunikasi interpersonal yang semakin baik, maka komitmen organisasi anggota juga semakin baik, begitu pula sebaliknya.

Dukungan dan motivasi dari anggota yang lainnya sangat dibutuhkan oleh anggota untuk bisaa terus bersemangat di dalam menjalan program kerjanya, oleh karena itu sesama anggota perlu disadarkan untuk bisa saling mengenal bahkan mendukung, dan lebih dari hanya mengenal. Paling tidak dengan anggotaanggota dari bidang yang sama. Dukungan dan motivasi dalam organisasi ini penting melihat hasil penelitian Febriananda et al. (2009) yang menjelaskan bahwa pengaruh atau sikap anggota yang yang mendukung dalam setiap kegiatan organisasi akan menghasilkan output yang maksimal baik dari segi kuantitas maupun kualitas dan dirasakan langsung manfaatnya untuk anggota, maka hal ini dapat meningkatkan peran organisasi. Hubungan dan komunikasi sesama anggota yang saling mendukung menjadi semakin kuat dengan hasil penelitian Ahadi (2012) yang menjelaskan bahwa iklim komunikasi suportif yang tinggi akan diikuti komitmen afektif bagi anggota. Pradipto et al. (2017) mengungkapkan bahwa komunikasi persuasif adalah kunci dalam membina hubungan antar anggota komunitas dengan mengaktifkan komunikasi kelompok dan organisasi yang terus menerus akan mampu menyelaraskan keinginan kelompok dalam mewujudkan visi Bogor Ngariung.

\section{Kepuasan Anggota Terhadap Bogor Ngariung}

\section{Peran Manajer}

Bagi informan manajer dalam mengelola Bogor Ngariung adalah pihak yang paling berperan dan vital dalam kelangsungan pengelolaan Bogor Ngariung dan berkomunikasi dengan yang lain, baik internal, baik pihak ketiga seperti media, perusahaan dan pemerintah. Hasil temuan yang menjelaskan manajer bertindak sebagai pihak yang paling berperan dan vital ini semakin diperkuat dengan hasil penelitian Nurudin (2012) yang mengutarakan bahwa manajer merupakan pemain utama, dengan bekal yang ada tersebut manajer dapat berapresiasi dengan lebih baik dalam menghadapi segala permasalan yang cenderung menghambat bahkan dengan kemampuannya pula ia dapat mengubah tantangan menjadi peluang. Namun, bagi informan, akhir-akhir ini peran manajer termasuk kurang baik, tidak semua manajer terlihat berperan, dan hanya hanya ada beberapa saja.

Peran manajer dalam mendengarkan ide dan keluh kesah juga dirasa belum merata ke semua anggota, hal itu terbukti dengan adanya pendapat informan yang sudah pernah didengar dengan diajak diskusi, dan ada juga yang belum. Meski belum pernah mendengarkan semua ide dan keluh kesah seluruh informan secara menyeluruh, namun hubungan anggota dan manajer terbilang baik, tanpa konflik dan juga berjalan lancar-lancar saja. Peran manajer dalam mendengarkan ide, keluh kesah dan bersama-sama menciptakan solusi dirasa perlu, hal itu dapat dilihat dari hasil penelitian Nasikhah dan Nanik (2015) yang menjelaskan peran koordinator antara lain melalui keteladanan, wejangan (talk) dan mengadakan program-program yang secara tidak langsung dapat mengendalikan perilaku anggota. Untuk itu diharapkan Koordinator Bogor Ngariung dapat berperan lebih dari yang ada.

Rasa puas para anggota komunitas terhadap manajer Bogor Ngariung diharapkan dapat lebih kooperatif dengan blusukan ke komunitas sehingga tahu masalah yang sedang dihadapi anggota, dapat membantu menyelesaikan masalah. Selain itu manajer juga diharapkan dapat menularkan semangat kerja sama dan perubahan kepada sesama anggota, dapat 
memanfaatkan sosial medianya untuk membantu menyebarkan informasi komunitas dan perlu regenerasi. Pendapat informan yang dinilai kurang baik ini dapat menjadi evaluasi bagi manajer atau koordinator Bogor Ngariung agar dapat lebih baik, Taufik (2013) untuk keberhasilan pencapaian kinerja instansi, dilakukan monitoring dan evaluasi yang bertujuan untuk perbaikan pencapaian standar pelayanan minimum (SPM), dan bahan masukan bagi pengembangan kapasitas. Selain itu sebagai bahan pertimbangan dalam pembinaan dan pengawasan hal itu dirasa perlu karena manajer memiliki peran dalam dalam memuaskan anggotanya, hal itu seperti hasil temuan dari Jayatri dan Samian (2010) yang menjelaskan bahwa hubungan antara peranan manajer dengan kepuasan kerja karyawan adalah hubungan yang positif dan linier dan berkorelasi sangat kuat, yang memiliki arti bahwa semakin baik peran yang dimainkan oleh manajer maka akan semakin tinggi pula kepuasan kerja karyawan. Darlis dan Cahayani (2013) memperkuat pentingnya peran manajerial dengan kejelasan peran terhadap kinerja manajerial.

Adapun peran manajer yang sudah dirasakan oleh informan adalah (1) mengelola Bogor Ngariung. (2) menyambungkan komunikasi sesama anggota. (3) meyambungkan komunikasi dan kerja sama antara anggota dengan instansi, media, dan pemerintah.

Komunikasi menjadi hal sangat dirasakan oleh informan. Hal itu senada dengan temuan penelitian Porwani (2014) bahwa komunikasi memiliki peran penting terhadap fungsi-fungsi manajemen di PT. Astra International-Honda, hal tersebut terlihat dengan beberapa pelaksanaan fungsi manajemen yang tidak dapat terlepas dari fungsi komunikasi, dalam melaksanakan fungsi pengorganisasian di sini komunikasi sebagai fungsi regulatif memiliki peran dimana orang-orang yang berada dalam tataran manajemen memilliki kewenangan untuk mengendalikan semua informasi yang berhubungan dengan bidang akademik, dan keahlian karyawan serta membuat batasan-batasan tentang apa saja yang boleh dan tidak boleh dilakukan di perusahaan tersebut.

\section{Kecukupan Informasi}

Prabawanti (2008) menjelaskan komunikasi yang paling sering dianggap penting oleh banyak orang dalam rangka pencapaian tujuan organisasi adalah komunikasi dengan bentuk penyebaran informasi. Artinya, tujuan komunikasi adalah penyebaran informasi mengenai perubahan sehingga perubahan dapat diterima oleh anggota organisasi. Persebaran informasi yang ada di grup terbilang baik meski masih ada beberapa yang terkadang ketinggalan informasi, hal itu terjadi karena perwakilan anggota di dalam grup ada yang kurang aktif berkomunikasi menggunakan LINE, dan ada juga perwakilan yang terkadang kurang aktif untuk menyebarkan informasi ke komunitasnya. Aktifnya perwakilan di dalam grup koordinasi dirasa sangat penting karena menurut hasil penelitian Poetra (2016) menjelaskan bahwa grup aplikasi LINE anggota digunakan sebagai aktivitas pengganti pertemuan langgsung, sarana penanganan hal-hal mendesak dan usaha menjaga keefektifan anggota. Selaras denga Pradipto et al. (2017) menjelaskan bahwa komunikasi persuasif antar anggota mampu meningkatkan semangat anggota serta loyalitas anggota dalam berbagai kegiatan. Hal ini tampak dari struktur pengurusan yang jelas siapa dan apa yang menjadi juru bicara dan diskusi yang diangkat. Hal serupa juga diungkapkan oleh Sukrillah et al. (2017) bahwa komunitas hendaklah memiliki informasi yang cukup jelas dan cukup baik dalam mengemasnya sehingga mampu dipahami setiap anggota dalam setiap rencana kerja yang dimiliki komunitas.

Informasi dan juga pemilihan teknologi informasi di dalam penelitian ini dianggap penting, meskipun persebaran informasi 
sudah dianggap baik, namun informan berharap persebaran informasi bisa lebih baik lagi dengan media yang sesuai dan teknologi informasi lainnya, hal ini senada dengan hasil penelitian Tamzil (2003) yang menemukan bahwa peranan teknologi informasi dalam bidang komunikasi sangatlah besar, karena dalam adanya informasi yang mendukung, akan terciptalah komunikasi yang efektif.

\section{Integrasi Sesama Anggota}

Semua informan menyatakan pendapatnya bahwa pernah melakukan integrasi dengan anggota lain untuk memudahkan program kerja mereka, dari mulai berkolaborasi membuka kegiatan lapak baca bagi anggota dari bidang literasi, bekerja sama dengan anggota dari bidang seni untuk menghibur anak didik anggota dari bidang pendidikan dan juga integrasi untuk mengadakan kegiatan kelas belajar bersama. Hubungan baik dan integrasi sesama anggota di dalam lingkungan organisasi Bogor Ngariung dalam menciptakan kolaborasi merupakan fakta yang baik, Erwiza (2014) mengungkapkan bahwa pengintergrasian memanglah merupakan satu hal penting dari sekian banyak hal penting dalam sebuah organisasi atau perusahaan. dimana dalam pengintgresian pasti terjadinya proses saling membutukan, saling memuaskan, saling menguntukan dan hal tersebut dapat menjadi faktor motivasi dalam mewujudkan tujuan organisasi dan program kerja. Hal ini diperkuat oleh Saparso (2006) yang menjelaskan pada era kompetitif di abat 21 ini mungkin ingin menciptakan tempat kerja kolaboratif. Di saat kondisi yang tidak pasti, tempat kerja menitik beratkan pada kerja sama. Pradipto et al. (2017) integrasi sesama anggota dapat diciptakan dengan menumbuhkan solidaritas antar sesama dengan meningkatkan intesitas pertemuan anggota dalam setiap kegiatan.

\section{Pendorong Kepuasan}

Jejaring, atau relasi atau yang bisa juga disebut sebagai mitra atau kemitraan merupakan pendorong yang paling dominan dari rasa puas terhadap audit komunikasi organisasi di Bogor Ngariung. Era yang menyebutkan sudah saatnya kerja baik dan bukan kerja sendiri ini dibuktikan oleh Bogor Ngariung. Pratama (2015) jejaring merupakan sebuah struktur yang didalamnya terdapat berbagai aktor yang saling terhubung. Baiknya peran jejaring ini juga diperkuat oleh hasil penelitian tentang kemitraan di ranah bisnis dari Widyana (2013) ini menjelaskan kemitraan dalam perkembangannya sangat membantu berinovasi dan melakukan pengembangan sehingga hasil produk dapat bersaing dengan produk domestik dan produk internasional. Hal ini didukung oleh studi Nuhajati (2010) bahwa semakin tinggi kualitas jejaring yang dimiliki suatu organisasi akan semakin besar kemampuan organisasi dalam mengembangkan inovasi organisasi.

\section{Strategi Bogor Ngariung Memberikan Kepuasan Kepada Anggota}

Audit komunikasi organisasi di lingkungan Bogor Ngariung yang dilakukan oleh peneliti tidak hanya menggali informasi dari informan yang menjadi anggota. Peneliti menggali dan mencari tahu strategi dan langkah yang sudah dilakukan oleh koordinator Bogor Ngariung. Dalam hal ini peneliti mencoba menemui salah satu koordinator yang juga merupakan salah satu dari pendiri Bogor Ngariung. Nurhuda Anwar atau yang akrab dipanggil Kang Ace menjelaskan bahwa ada beberapa hal yang sudah dilakukan oleh koordinator Bogor Ngariung untuk menjalankan Bogor Ngariung dan melayani anggota. Adapun strategi tersebut adalah: 


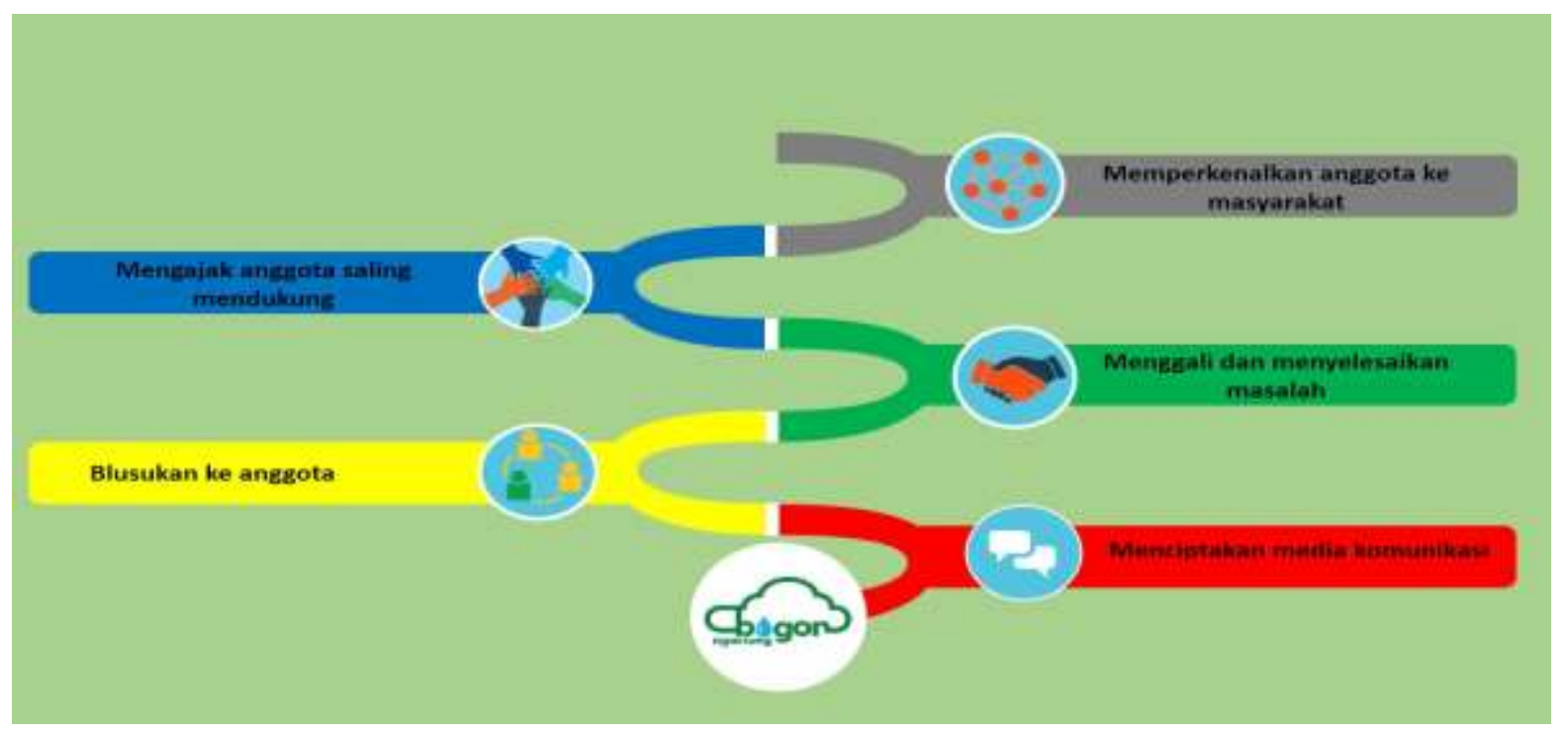

Gambar 1. Strategi aktivitas kegiatan Bogor Ngariung

Secara keseluruhan kita dapat membaca bahwa peran manajer Bogor Ngariung adalah pada ranah koordinasi dimana mengkoordinasikan antar anggota, menjembatani, mencoba menggali dan menyelesaikan masalah dan juga menjalin kerja sama dengan pihak luar. Peran yang dilakukan oleh Koordinator Bogor Ngariung sudah sesuai dimana menurut Saparso (2006) semua peran ini dipenuhi demi suksesnya fungsi kepemimpinan di tempat kerja kolaboratif. Berdasarkan halhal tersebut diatas pemimpin kolaboratif diharapkan bertindak lain dalam pemikiran, perasaan dan jiwa atau sering berpikir melalui otak, hati dan jiwa. Selain itu seorang pemimpin harus mampu menciptakan sikap dan perlaku anggotanya menjadi rasa ikut memiliki, rasa ikut bertanggung jawab dan mawas diri. Pemimpin kolaboratif diharapkan melakukan hal-hal sebagai berikut: (a) memastikan aliansi strategis di antara semua stockholder kunci dalam organisasi, dengan pelanggan dan pasar. (b) Memastikan keharmonisan di antara semua unsur organisasi, dengan fokus pada proses dan integritas internalnya. Segala strategi yang pernah dijalankan dan rencana ke depan sebaiknya dilaksanakan dengan baik karena, Kusumawijaya (2011), semakin baik pelaksanaan peran mitra strategis dan agen perubahan manajer diikuti oleh semakin baiknya pelaksanaan manajemen talenta serta terjadi peningkatan kinerja anggota.

\section{KESIMPULAN DAN SARAN}

\section{Kesimpulan}

1. Hubungan antar anggota yang baik merupakan kegiatan komunikasi organisasi yang baik dan perlu diperkuat dengan kegiatn pertemuan langsung atau Ngariung Komunitas dan pemilihan media komunikasi yang sesuai.
2. Rasa puas dari anggota terhadap komunitas Bogor Ngariung dinampakkan dalam jejaring atau dapat mengenal satu sama lain, faktor pendorong yang paling mendominasi adalah peran manajer, kecukupan informasi, integrasi sesama anggota,

3. Strategi manajemen Bogor Ngariung untuk memberikan kepuasan kepada 
anggota diwujudkan melalui .jejaring dan integrasi sesama anggota dengan mengoptimalkan penggunaan media komunikasi.

\section{Saran}

Adapun saran yang dapat direkomendasikan dalam penelitian ini :

1. Pemanfaatan media komunikasi yang digunakan secara massive dan ngariung komunitas yang lebih terjadwal, kemudian keduanya dilakukan dengan pendekatan berbasis edukasi dan hiburan.

2. Perlunya kaderisasi manajer untuk memberikan peran yang signifikan untuk anggota.

3. Perlunya kerja sama antar anggota untuk saling bahu-membahu dan membantu sesama anggota lainnya.

\section{DAFTAR PUSTAKA}

Adhi S. 2014. Exploring Facebook and Whatsapp As Supporting Social Network Apllications For English Learning In Higher Education. Bandung (ID): Widyatama.

Ahadi MN. 2012. Hubungan Antara Iklim Komunikasi Suportif dan Motivasi Berorganisasi dengan Komitmen Afektif Anggota Remaja Islam Masjid Agung Jawa Tengah. [Skripsi]. Semarang (ID). Universitas Diponegoro.

Anna N. 2009. Peran Pemimpin dalam Menciptakan Knowledge Sharing di Organisasi. [Skripsi]. Surabaya (ID). Universitas Airlangga.

Bungin B. 2013. Sosiologi Komunikasi. Jakarta (ID): Prenada Media Group.

Darlis E, Cahayani A. 2013. Kejelasan Peran dan Pemberdayaan Psikologis dalam Peningkatan Kinerja Manajerial. Jurnal Ekonomi. 21 (03): 1-14.

Desya W. 2017. Saatnya Komunitas Bogor Menjadi Pegiat Perubahan. Diterbitkan oleh Harian Radar Bogor pada tanggal 4 Oktober 2017.
Dudung. 2015. 6 Pengertian Komunitas Menurut Parah Ahli. Diunduh pada pranala

http://www.dosenpendidikan.com/6pengertian-komunitas-menurut-paraahli/ pada tanggal 4 Desember 2017, pukul 15.00 WIB.

Febriananda E. 2014. Pengaruh Kepemimpinan dan Dukungan Anggota Terhadap Peran Serikat Pekerja PT. PLN PERSERO Area Tegal. [Skripsi]. Semarang (ID). Universitas Diponegoro.

Erwiza. 2014. Integrasi dan Motivasi Kerja. [Skripsi]. Pekanbaru (ID). UIN Sultan Syarif Kasim.

Jayatri A, Samian. 2010. Hubungan antara Peranan Manajer dengan Kepuasan Kerja pada Karyawan PT. Perkebunan Nusnatara X (PERSERO) di PG. Toelangan Sidoarja. [Skripsi]. Surabaya (ID). Universitas Airlangga.

Kertonegoro S. 1994. Manajemen Organisasi. Jakarta (ID): Widya Press Jakarta. 
Kriyantono R. 2012. Teknis Praktis Riset Komunikasi. Jakarta (ID): Prenada Media Group.

Kusumawijaya IK. 2011. Peran Mitra Strategis dan Agen Perubahan dalam Manajemen Talenta dan Kinerja Manajer. Jurnal Siasat Bisnis. 15 (1) : 125-143.

Lani dan Hari. 2017. Bima Arya Buka Puasa Bersama dengan Puluhan Komunitas. diunduh dari pranala http://kotabogor.go.id/index.php/show _post/detail/7206/bima-arya-bukapuasa-bersama-dengan-puluhankomunitas\#.Wk4rGdJl_IU pada tanggal 4 Januari 2017, pukul 20.00 WIB.

Masitoh ID. 2015. Peran Whatsapp Sebagai Media Komunikasi Pada Komunitas One Day One Juzz (ODOZ). [Skripsi]. Banten (ID). Surya University

Mohammed R, Bungin B. 2015. Audit Komunikasi. Jakarta (ID): Prenada Media Group.

Nasikhah Z, dan Setyowati RN. 2005. Peran Koordinator Bonek dalam Mengendalikan Perilaku Agresif Suporter PERSEBAYA (BONEK) di Surabaya. [Skripsi]. Surabaya (ID). Universitas Negeri Surabaya.

Nurhajati T. 2010. Model Pengembangan Kinerja Organisasi Melalui Kualitas Jejaring, Kualitas Kepercayaan dan Inovasi. [Skripsi]. Semarang (ID). Universitas Sultan Agung.

Nurudin. 2012. Pengaruh Kemampuan Manajerial dan Kematangan Bawahan Terhadap Efektivitas Gaya Kepemimpinan Kepala Sekolah. [Skripsi]. Semarang (ID). Universitas Sultan Agung.

Poetra AW. 2016. Komunikasi Anggota Himpunan dalam Aplikasi Line. [Skripsi]. Bandung (ID). Universitas Padjajaran.
Porwani S. 2014. Peran Komunikasi dalam Fungsi Manajemen pada PT. Astra International-Honda TBK Plaju Palembang. [Skripsi]. Palembang (ID). Politeknik Negeri Sriwijaya.

Pradipto NA, Sukarelawati, Kusumadinata AA. 2017. Pengaruh Komunikasi Persuasif dalam Meningkatkan Kesadaran Solidaritas Anggota Scooter Mods Bogor Indonesia. Jurnal Komunikatio. 3(2) : 61-68.

Prabawanti BE. 2008. Peran Komunikasi sebagai Pendukung Perubahan Organisasi. [Tesis]. Bandung (ID). Universitas Parahyangan

Pratama A. 2015. Jejaring Kerja Organisasi dalam Pencegahan HIV/AIDS di Kabupaten Kediri. [Skripsi]. Malang (ID). Universitas Brawijaya.

Ramdani D. 2015. Audit Komunikasi: Organisasi Wahana Lingkungan Hidup Indonesia (WALHI) Yogyakarta. [Skripsi]. Yogyakarta (ID). Universitas Pembangunan Nasional.

Ruliana P. 2016. Komunikasi Organisasi. Jakarta (ID): Raja Grafindo Persada.

Saparso. 2006. Peranan Unsur Kolaborasi Dalam Organisasi. Jurnal Manajemen Krida Wacana. 6 (2): 117-130.

Sari WP. 2009. Audit Komunikasi Sebagai Alat untuk Mengukur Efektivitas dan Efisiensi Komunikasi dalam Suatu Organisasi. [Tesis]. Jakarta (ID): Universitas Budi Luhur.

Setyawan FB. 2016. Solidaritas Sosial Anggota Komunitas Motor Honda Classic Magelang (HCM) Cub Series. [Skripsi]. Yogyakarta (ID). UIN Sunan Kalijaga Yogyakarta

Setyono F. 2013. Pengaruh Kualitas Komunikasi Interpersonal Pemimpin Kelompok Sel terhadap Komitmen 
Organisasi Anggota Kelompok Sel di Satelit Toly Gereja Mawar Sharon Surabaya. [Skripsi]. Surabaya (ID). Universitas Kristen Petra Surabaya.

Soekanto S. 2015. Sosiologi Suatu Pengantar. Jakarta (ID) : Raja Grafindo Persada.

Sukrillah A, Ratnamulyani IA, Kusumadinata AA. 2017. Pemanfaatan Media Sosial Melalui Whatsapp Group Fei Sebagai Sarana Komunikasi. Jurnal Komunikatio. 3(2): 95-104.
Taufik T. 2013. Peran Monitoring dan Evaluasi Terhadap Sistem Akuntabilitas Kinerja Instansi Pemerintah Daerah. Jurnal Akuntasi. 1(2) : 199-122.

Tamzil F. 2003. Peran Teknologi Informasi dalam Dunia Komunikasi. [Skripsi]. Jakarta (ID). Universitas Esa Unggul.

Widyana W. 2013. Pentingnya Pola Kemitraan dalam Rangka Meningkatkan Peran dan Kinerja Usaha Mikro Kecil, dan Menengah di Jawa Timur Periode 20062011. [Skripsi]. Surabaya (ID). Universitas Surabaya. 